\title{
PENGGUNAAN METODE DALCROZE DALAM PEMBELAJARAN PIANIKA DI SMA NEGERI 1 TANJUNG RAJA
}

\author{
Syaflinawati \\ Program Studi Pendidikan Seni Pertunjukan, STKIP Rosalia Lampung \\ Jl. Soekarno Hatta, Mulyojati 16C Kota Metro-Lampung \\ Email : syaflinawati17@gmail.com
}

\begin{abstract}
Pianica is a small wind instrument similar to a harmonica, using keyboard blades which has rangeabout three octaves, played by blowing using a flexible pipe connected to the mouth. Pianica learning is designed to train students mentally and physically so that they can interact with others in the form of interactions between students and teachers, the environment, and other learning resources. Furthermore, this study aims to explain the application of the dalcroze method in the pianica learning process and pianica playing techniques using the dalcroze method. The method used in this study refers to the qualitative method using data collection techniques obtained through observation, interviews and field documentation. The results of this study refer to: First, learning pianica is a practical lesson that is useful for improving the skills and abilities and skills of students in playing the musical instrument. In this context, learning dalcroze eurythmics is closely related to solphegio (hearing exercises), improvisation, and eurythmics. Second, the technique of playing the pianica using the dalcroze method is to provide insight and understanding of learning theory, as well as practice. In this case, learning pianica using the Dalcroze method helps the creativity of students in the learning process because it indirectly teaches students to be more thorough, understand and be sensitive to the circumstances or instincts they have.
\end{abstract}

Key word : Pianica, dalcroze method

\begin{abstract}
ABSTRAK
Pianika merupakan alat musik tiup kecil sejenis harmonika, menggunakan bilah-bilah keyboard dengan luas sekitar tiga oktaf, dimainkan dengan cara ditiup menggunakan pipa lentur yang dihubungkan ke bagian mulut. Pada dasarnya, pembelajaran pianika dirancang untuk melatih mental dan fisik para peserta didik agar dapat berinteraksi dengan sesama baik berupa interaksi antar peserta didik dengan guru, lingkungan, dan sumber pembelajaran lainnya. Selanjutnya, penelitian ini bertujuan untuk menjelaskan penerapan metode dalcroze pada proses pembelajaran pianika dan teknik permainan pianika dengan menggunakan metode dalcroze. Metode yang digunakan pada penelitian ini mengacu pada metode kualitatif dengan menggunakan teknik pengumpulan data yang didapat melalui observasi, wawancara dan dokumentasi dilapangan. Adapun hasil penelitian ini, mengacu pada : Pertama, Pembelajaran pianika merupakan pelajaran praktek yang bermanfaat untuk meningkatkan skill dan kemampuan serta keterampilan peserta didik dalam memainkan alat musik tersebut. Pada konteks ini, pembelajaran euritmika dalcroze berkaitan erat dengan: solfegio (latihan pendengaran), improvisasi, dan euritmik. Kedua, teknik permainan pianika dengan menggunakan metode dalcroze adalah dengan cara memberikan wawasan dan pemahaman tentang pembelajaran teori, maupun praktek. Dalam hal ini, pembelajaran pianika dengan menggunakan metode dalcroze sangat membantu kreatifitas para peserta didik dalam proses pembelajaran karena secara tidak langsung mengajarkan para peserta dididik untuk lebih teliti, memahami dan peka dengan keadaan ataupun insting yang mereka miliki.
\end{abstract}

Kata Kunci : Pianika, metode dalcroze 


\section{Pendahuluan}

Pendidikan merupakan proses pengalihan pengetahuan secara sadar dan terencana untuk mengubah tingkah laku manusia dan mendewasakan manusia melalui proses pengajaran dalam bentuk pendidikan formal, nonformal, dan informal. (Irham dkk, 2013: 19). Dengan kata lain, pendidikan merupakan suatu hal yang sangat penting dan tidak dapat dipisahkan dalam kehidupan berbangsa dan bernegara. Di mana maju mundurnya suatu bangsa ditentukan oleh maju mundurnya pendidikan dari suatu bangsa tersebut.

Nata (2009: 85), memaknai melihat pembelajaran sebagai sebuah usaha untuk mempengaruhi emosi, intelektual, dan spiritual seseorang agar memiliki keinginan untuk belajar sesuai dengan kehendaknya sendiri tanpa adanya paksaan dari orang lain. Melalui pembelajaran akan terjadi proses pengembangan moral baik dari segi keagamaan, aktivitas, dan kreativitas peserta didik melalui berbagai interaksi ataupun pengalaman belajar.

Berdasarkan Undang-Undang Republik Indonesia Nomor 20 Tahun 2003, tentang Sistem Pendidikan Nasional mewajibkan penyelenggaraan pendidikan memegang beberapa prinsip diantaranya pendidikan diselenggarakan secara demokratis dan berkeadilan serta tidak diskriminatif dengan menjunjung tinggi hak asasi manusia, nilai keagamaan, nilai kultural, dan kemajemukan bangsa dengan satu kesatuan yang sistemik dengan sistem terbuka dan multimakna.

Selain itu, penyelenggaraan juga harus dalam suatu proses pembudayaan dan pemberdayaan peserta didik yang berlangsung sepanjang hayat dengan memberikan keteladanan, membangun etos kerja/kemauan dan mengembangkan kreativitas peserta didik dengan mengembangkan budaya membaca, menulis, dan berhitung dalam penyelenggaraan dan pengendalian mutu layanan pendidikan. Selain itu, Undang-Undang Republik Indonesia Nomor 20 Tahun 2003 juga mewajibkan kurikulum Pendidikan Dasar dan Menengah agar memuat pembelajaran seni dan budaya. Secara umum seni dikelompokkan kedalam lima macam pengelompokan yakni seni tari, seni musik, seni drama/teater, seni rupa dan seni sastra.

Pembelajaran seni musik merupakan salah satu bentuk pembelajaran yang digunakan untuk mengembangkan daya dan kreatifitas seseorang agar mampu meningkatkan psikomotorik dan kepekaan kemampuan para peserta didik (Tarmizi dkk, 2019 : 29). Pada penelitian ini, pembahasan terpusat pada seni musik dengan menggunakan Metode Dalcroze.

Musik dalam dunia Pendidikan memiliki peranan yang sangat penting. Pada konteks ini, musik berfungsi sebagai keseimbangan untuk menyelaraskan antara otak kanan dan otak kiri manusia. Selain itu, pembelajaran seni musik memiliki peran penting untuk membentuk karakter dan mengembangkan potensi peserta didik agar memahami rasa keindahan dan memiliki kepekaan terutama dalam hal pengalaman dan penghayatan.
Sejalan dengan itu, Rien (1999:1) berpendapat bahwa menurut para pakar, pendidikan seni musik sangat berperan penting dalam kehidupan seorang peserta didik. Di mana banyak ditemukan para peserta didik yang berpartisipasi untuk kegiatan seni musik, selain dapat mengembangkan kreativitas, seni musik juga dapat membantu perkembangan individu, pengembangan sensitivitas, membangun rasa keindahan, mengungkapkan ekspresi, memberikan tantangan, melatih kedisiplinan dan mengenalkan peserta didik pada sejarah dan budaya bangsa mereka sendiri.

Pembelajaran seni musik khususnya dalam materi Pianika di SMA Negeri 1 Tanjung Raja, dilakukan pada saat Kegiatan Belajar Mengajar (KBM). Dalam hal ini, kegiatan belajar mengajar dirancang untuk memberikan pengalaman belajar denganmelibatkan proses mental dan fisik dan intelektual melalui interaksi antar peserta didik dengan guru, lingkungan dan sumber belajar lainnya dalam rangka pencapaian kompetensi dasar (Permendiknas No. 41 Tahun 2007).

Pembelajaran musik di SMA Negeri 1 Tanjung Raja, didukung dengan tersedianya fasilitas pendukung seperti studio musik lengkap dengan satu set peralatan band, peralatan musik rebana, alat musik tradisional gamolan pekhing, angklung dan alat musik pianika. Walaupun telah tersedianya sarana dan prasarana yang baik, masih banyak ditemukan sebagian besar peserta didik yang belum benar-benar memahami teknik/cara memainkan pianika dengan baik dan benar. Di mana kebanyakan pembelajaran yang digunakan oleh guru lebih cenderung menggunakan metode yang kurang variatif yakni hanya sebatas mengamati dan menirukan tanpa adanya inovasi dan kreativitas, serta masih banyak ditemukan para peserta didik yang belum dapat membaca notasi balok maupun notasi angka dari lagu yang dinyanyikan.

Oleh karena itu, penting bagi seorang peserta didik agar mempersiapkan materi dan inovasi yang terbarukan berbasis skil dan kemampuan untuk diterapkan pada proses pembelajaran, pelaksanaan pembelajaran dan metode pembelajaran yang akan digunakan agar tercapai proses pembelajaran yang lebih optimal. Untuk dapat melaksanakan pembelajaran musik di SMA dengan baik, ada baiknya peserta didik dapat memahami peranan dari masing-masing komponen pada saat proses pembelajaran terutama dalam pembelajaran seni musik. Salah satunya adalah memiliki keterampilan yang cukup untuk memainkan alat-alat musik pada saat pembelajaran seni musik, hal ini bertujuan untuk melatih para peserta didik agar dapat memainkan alat musik tersebut.

Pada penelitian ini, peneliti menggunakan metode penelitian kualitatif, untuk mendeskripsikan tentang pembelajaran pianika serta masalah atau kendala siswa yang ditemukan. Selain itu, penelitian ini juga bertujuan untuk mendeskripsikan, menginterprestasi dan menganalisis kondisi-kondisi yang terjadi secara mendalam tanpa mengubah fakta yang terjadi. Penelitian kualitatif disebut juga dengan penelitian naturalistik, di mana penelitian ini dilakukan secara fakta dengan melihat yang ada dilapangan secara apa adanya. 
Dalam hal ini, Sugiyono (2015: 1), menekankan bahwa bahwa penelitian kualitatif merupakan penelitian yang digunakan untuk meneliti kondisi suatu obyek secara alamiah dan apa adanya sesuai dengan fakta yang ditemukan dilapangan. Sejalan dengan itu Silversteun dan Auerbach (2003: 3), penelitian kualitatif merujuk pada qualitative research is reasearch that involves analyzing and interpretting texts and interviews in order to discover meaning full patterns descriptive of a partikular phenomenon. Pernyataan mengenai penelitian kualitatif ini digunakan untuk menganalisis fenomenafenomena yang ada pada pembelajara alat musik pianika melalui penelitian lapangan.

\section{Pembahasan}

A. Penerapan Metode Dalcroze Pada Pembelajaran Pianika di Kelas XI IPA 1 SMA N 1 Tanjung Raja

Pembelajaran pianika merupakan bagian penting dari mata pelajaran seni musik yang ada pada Kegiatan Belajar Mengajar (KBM). Pembelajaran pianika merupakan materi pokok yang terdapat pada kurikulum pembelajaran, khususnya pada tingkat SMA sederajat. Pembelajaran ini merupakan bagian dari mata pelajaran praktek sangat bermanfaat untuk meningkatkan skill dan kemampuan peserta didik untuk memainkan alat musik tersebut. Selain itu, pembelajaran ini juga bertujuan untuk meningkatkan kreatifitas peserta didik dalam hal memainkan alat musik, baik berupa lagu nasional maupun lagu daerah/tradisional dengan menggunakan metode delcroze.

Sejalan dengan itu, Jamalus (1988: 17-20), mengungkapkan bahwa metode Dalcroze lebih menekankan pada konsep-konsep musik terutama dalam apresiasi musik, latihan pendengaran dan improvisasi dalam rangka meningkatkan mutu serta kemampuan musikalitas. Dengan kata lain, pendekatan ini menjadi penghubung antara musik, gerakan, pikiran dan tubuh. Dalam hal ini, pandangan dalcroze terhadap pendidikan musik mencakup tiga aspek meliputi eurhythmic, improvisasi dan solfege.

Pada kegiatan pembelajaran pianika, peneliti menginstrusikan peserta didik untuk mengikuti pembelajaran dengan baik dan benar, agar kegiatan pembelajaran berjalan dengan lancar serta memberikan penjelasan mengenai eurhytmik, solfegio, dan improvisasi. Eurhytmik dalcroze mengajarkan konsep ritme, struktur dan ekspresi musik dengan menggunakan gerakan. Solfegio juga dapat diartikan sebagai suatu kegiatan untuk mengidentifikasi kepekaan musikal, baik berupa kemampuan untuk mengidentifikasi ritmik maupun kemampuan untuk mengidentifikasi melodi. Sedangkan improvisasi merupakan kemampuan peserta didik untuk mengembangkan skill dalam bentuk spontanitas, kreatifitas, data cipta dan daya khayal.

Biasanya, latihan Eurhytmic dan Solfegio diajarkan dalam bentuk demonstrasi. selanjutnya peserta didik diberikan arahan atau instruksi untuk membuat dua kelompok. Untuk kelompok pertama, peneliti memberikan contoh berupa pola gerakan eurhytmik. Pada konteks ini, peserta didik diarahkan untuk melakukan langkah-langkah kecil sesuai dengan irama musik 4/4 dan $3 / 4$.

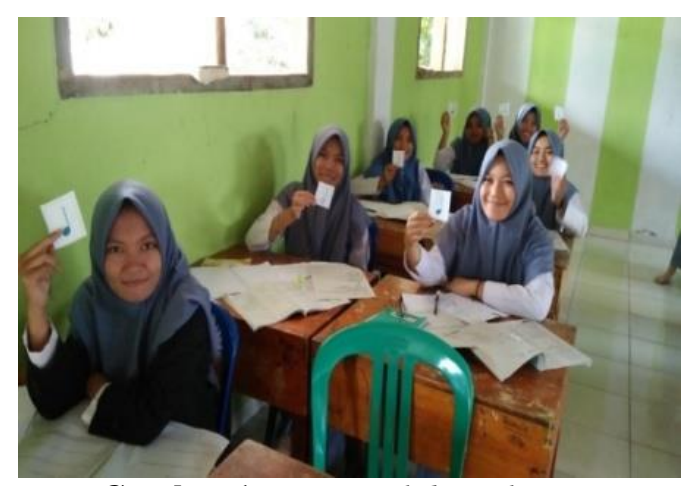

Gambar 1. Mengenali bentuk notasi

(Dokumentasi Fot:o Syaflinawati, 2020)

Pada pola gerakan ini, sebagian besar peserta didik dapat melakukan gerakan dengan baik sesuai musik yang dibunyikan. Dalam hal ini, hanya ada beberapa peserta didik yang tidak memperhatikan dan kurang memahami materi pada saat diberikan instruksi. Setelah kelompok pertama selesai, kemudian dilanjutkan dengan kelompok kedua dengan menggunakan pola gerakan yang sama. Kelompok kedua lebih baik dari pada kelompok pertama, karena mereka sudah memperhatikan dan mengamati kelompok sebelumnya.

Setelah pelatihan eurhytmik selesai dilakukan, kemudian dilanjutkan dengan pelatihan solfegio. Pada latihan solfegio, peneliti menginstrusikan kepada para peserta didik untuk berbaris dimulai dari kelompok pertama, dimana kelompok pertama ini dibagi menjadi dua barisan. Pada kegiatan ini, pertama-tama peneliti memainkan sebuah melodi dengan menggunakan keyboard, jika melodi tersebut naik maka peserta didik yang berada dibarisan paling belakang harus berpindah posisi ke barisan paling depan dan jika pergerakan melodinya turun maka peserta didik yang berada dibarisan paling depan berpindah kebelakang. Begitu juga dengan melodi yang dimainkan tetap, maka diinstruksikan kepada para peserta didik untuk memutarkan badannya searah jarum jam.

Adapun kegiatan selanjutnya adalah mengajarkan para peserta didik untuk membaca not 1/2, 1/4, 1/8, dan $1 / 4$ titik 1/8 dalam sukat 4/4. Dalam hal ini, peneliti mengajarkan mereka dengan cara memberikan contoh terlebih dahulu melalui tepukan tangan yang telah disesuaikan dengan not yang ada dipapan tulis.

\begin{tabular}{|r|c|c|}
\hline Bentuk Not & Harga/nilai & Jumlah ketukan \\
\hline \hline$d$ & $1 / 2$ & 2 \\
\hline$d$ & $1 / 4$ & 1 \\
\hline$d$ & $1 / 8$ & $1 / 2$ \\
\hline J & $1 / 16$ & $1 / 4$ \\
\hline
\end{tabular}

Gambar 2. Not 1/2, 1/4, 1/8, dan 1/4 titik 1/8. 
Kegiatan peneliti selanjutnya adalah membagikan kartu-kartu yang telah di siapkan secara acak di mana setiap kelompok mendapatkan sembilan kartu dan tentunya pada masing-masing kartu tersebut telah diberikan gambar serta warna not yang sama seperti gambar di atas. Pada kegiatan ini, peneliti menginstruksikan kepada para peserta didik untuk menyusun kartu tersebut sesuai dengan kelompok masing-masing. Hal ini merupakan proses terakhir dari metode dalcroze yakni berupa improvisasi, yang bertujuan agar peserta didik mampu membedakan susunan notasi dengan benar. Adapun not yang telah disusun oleh kelompok pertama meliputi : 1/4, 1/2, 1/4, $1 / 8,1 / 4$ titik $1 / 8,1 / 2,1 / 4,1 / 4,1 / 4$ titik $1 / 8$, sedangkan not yang disusun kelompok kedua meliputi : 1/2, 1/4, 1/4 titik 1/8, 1/2, $1 / 4$ titik 1/8, 1/4 titik 1/8, 1/8, 1/8, 1/8.

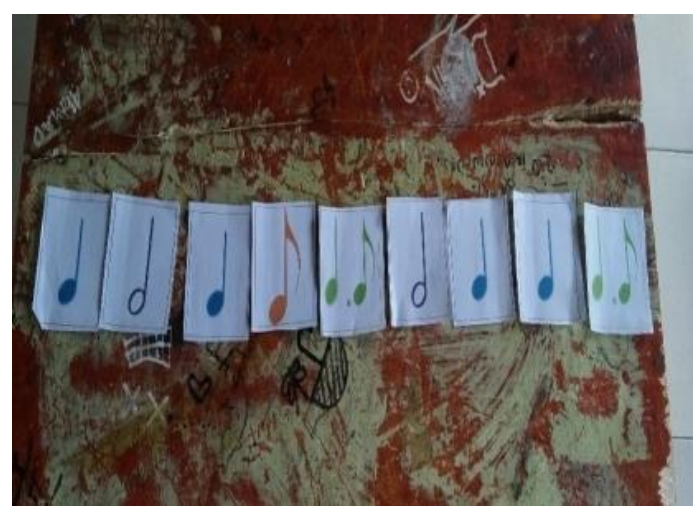

Gambar 3. Kartu Notasi Yang Disusun Kelompok 1

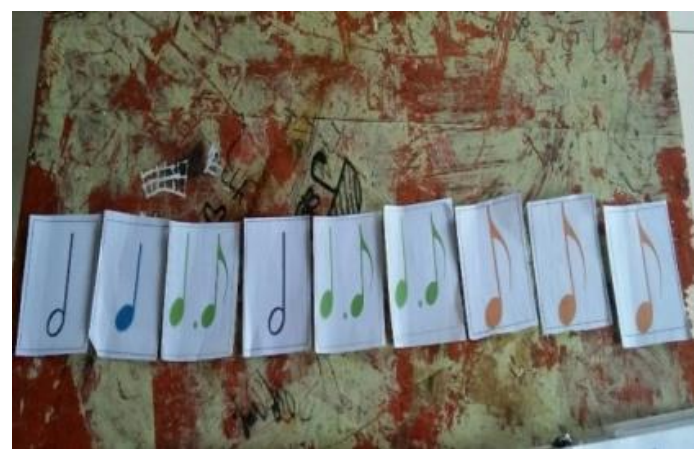

Gambar 4. Kartu Notasi Yang Disusun Kelompok 2

Dalam hal ini, masih banyak ditemukan para peserta didik yang mengalami kesulitan terutama dalam membaca not 1/4 titik 1/8. Berdasarkan hasil pengamatan peneliti selama proses pembelajaran, ditemukan beberapa kendala dalam proses pembelajaran yang telah berlangsung yakni masih terdapat peserta didik yang kurang fokus dalam belajar dan masih ditemukan peserta didik mengalami kesulitan terutama dalam hal membaca not $1 / 8$ dan $1 / 4$ titik $1 / 8$. Sedangkan pada not yang lain seperti not $1 / 2,1 / 4$, peserta didik dapat membaca dan memainkannya dengan baik dan benar.
Setelah peserta didik memahami notasi, selanjutnya peneliti memberikan materi pola ritme lagu daerah yang telah dipersiapkan, yaitu materi lagu "Gundul-Gundul Pacul".

\section{Gundul-Gundul Pacul}

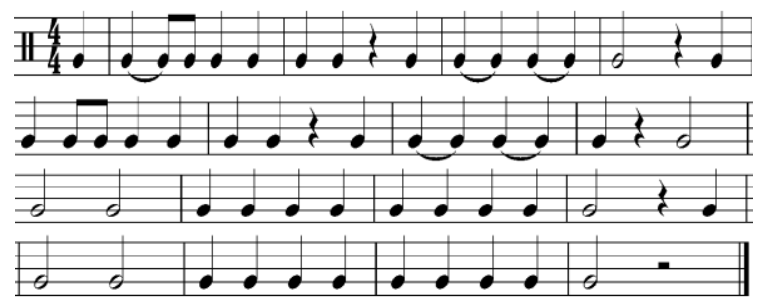

Gambar 5. Pola Ritme Lagu Gundul Gundul Pacul.

Adapun cara memainkan not tersebut adalah melalui tepuk tangan per kelompok yang dilakukan secara bergantian, selanjutnya peneliti memberikan arahan dan membimbing kepada para peserta didik agar dapat memainkan not dengan benar sesuai dengan ritme dan tempo yang telah ditentukan. Dalam hal ini, kegiatan tersebut dilakukan secara berulang-ulang agar peserta didik lebih memahami dan mudah merespon terkait materi yang diajarkan. Langkah selanjutnya yang peneliti lakukan adalah dengan memberikan notasi angka serta teks lagu yang akan dimainkan. Hal ini bertujuan agar not tersebut dapat dimainkan secara baik dan benar dengan menggunakan instrumen musik.

\section{Gundhul Pacul}

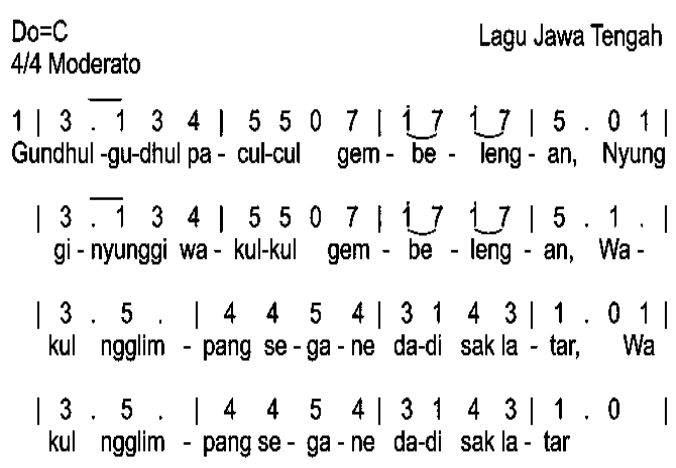

Gambar 6. Notasi Angka Lagu Gundul-Gundul Pacul

Langkah selanjutnya, peneliti memberikan instruksi kepada peserta didik untuk memainkan not tersebut dengan menggunakan alat musik pianika. Namun sebelum masuk pada tahap tersebut, peserta didik diinstruksikan untuk menyanyikan notasi angka secara bersama-sama sesuai dengan nada, ritme dan tempo dengan baik dan benar. Pada konteks ini, peserta didik menyanyikannya dengan nada Sol $\mathrm{Mi} \mathrm{Sa} \mathrm{Si}$ sesuai simbol angka yang telah dituliskan. Setelah itu peserta didik diminta untuk memainkan nada tersebut dengan menggunakan pianika secara bergantian. 


\section{B. Teknik Bermain Pianika Menggunakan Metode Dalcroze di Kelas XI IPA 1 SMA Negeri 1 Tanjung Raja}

Pianika merupakan jenis alat musik tiup kecil yang dimainkan dengan menggunakan pipa lentur yang dihubungkan ke mulut. Alat musik jenis ini tergolong pada alat musik tiup. Alat musik pianika juga disebut dengan melodian, yakni menggunakan bilah-bilah nada yang dimainkan dengan cara ditiup. Pada pianika juga terdapat 2 (dua) jenis tus yakni tuts yang berwarna putih dan tuts yang berwarna hitam, di mana kedua warna tuts tersebut masing-masing memiliki fungsi yang berbedabeda. Bilah-bilah nada pada tuts yang berwarna putih digunakan untuk memainkan nada-nada pokok atau nada asli, sedangkan bilah-bilah nada pada tuts yang berwarna hitam digunakan untuk memainkan nada-nada kromatis.

Disisi lain, pianika juga merupakan instrumen tiup, sebagaimana prinsip kerja harmonika yaitu dengan cara ditiup, tetapi memperoleh beraneka ragam nada yang diatur dan disesuaikan dengan tekanan nada pada bilahbilah nada seperti halnya papan nada pada instrumen alat musik piano. Untuk memainkan alat musik pianika adalah dengan cara posisi tangan bagian kiri memiliki fungsi untuk memegang pianika sedangkan posisi tangan kanan berfungsi untuk menekan melodi lagu serta mulut berfungsi untuk meniup selang agar dapat menghasilkan suara.

Pada prinsipnya pianika memiliki bilah-bilah keyboard sama halnya dengan piano, tetapi alat musik jenis ini memiliki bilah-bilah keyboard yang luasnya sekitar tiga oktaf. Umumnya pianika dimainkan sebagai alat musik pendidikan di sekolah. Biasanya alat musik pianika dapat dimainkan sebagai melodi pokok, kontra melodi, melodi sfiller, dan jika memungkinkan juga dapat berfungsi sebagai pengiring lagu.

Adapun beberapa tips dan teknik untuk memainkan alat musik pianika dengan baik dan benar adalah sebagai berikut :

1. Memainkan dengan lima jari, di mana setiap jari mempunyai tugas untuk menekan tuts-tuts tertentu.

2. Cara meniup diusahakan agar halus dan rata.

3. posisi tangan kanan seperti memegang bola sehingga memungkinkan jari-jari dapat bergerak dengan leluasa.

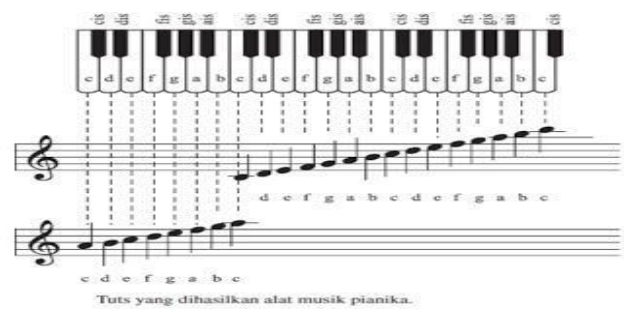

Gambar 7. Tuts pianika

Dalam memainkan alat musik pianika, posisi tangan hendaknya disesuaikan dengan petunjuk dan cara yang telah diajarkan/diinstruksikan yakni tangan kiri digunakan untuk memegang pianika sedangkan tangan kanan digunakan untuk menekan tuts pada melodi lagu, dan mulut digunakan untuk meniup dan mengatur tinggi rendahnya nada.

\section{Tangga Nada}

Nada merupakan suara yang dihasilkan dengan menggunakan frekuensi tertentu serta dilukiskan melalui simbol-simbol atau lambang-lambang tertentu (Banoe, 2011: 292). Sebagai contoh, nada A yang dipakai saat ini memiliki frekuensi $440 \mathrm{~Hz} /$ second sebagaimana yang telah ditetapkan oleh IMC (international Music Council). Dengan kata lain, dalam satu detik terjadi getaran sebanyak 440 kali. Pada saat ini yang dipakai dalam sistem nada internasional terdapat 12 nada pokok yang sudah dibakukan yakni : C, C\#, D, D\#, E, F, F\#, G, G\#, A, A\#, dan B. Di mana nada-nada tersebut dapat disusun menjadi sebuah tangga nada sesuai dengan intervalinterval pembentuk tangga nada tertentu.

Selain itu, tangga nada juga diartikan sebagai serangkaian nada dengan jarak tertentu yang dilakukan secara berulang-ulang. Sedangkan Allen Winold dan Jhon Rehn (1971: 206), berpendapat bahwa "scale is arrangement of pitches consecutive ascending or discending order", jika diartikan dalam Bahasa Indonesia tangga nada berarti "susunan titi nada yang berurutan dari urutan nada rendah ke nada tinggi atau nada tinggi ke rendah".

Dari pernyataan di atas, dapat ditarik suatu kesimpulan bahwa tangga nada akan selalu tersusun secara berurutan, bisa dari nada tinggi ke rendah maupun dari nada rendah ke tinggi secara alfabetis. Secara garis besar tangga nada dibagi menjadi tangga nada diatonik dan pentatonik. Tangga nada diatonis adalah sistem tangga nada yang pada masing-masing nada dalam tangga nada mempunyai jarak 1 tone, dan 1 semitone secara bervariasi.

Menurut Mudjilah (2004 : 21), terdapat dua jenis tangga nada diatonis, yaitu tangga nada mayor dan tangga nada minor.

\section{a. Tangga Nada Mayor}

Tangga nada mayor adalah susunan nada-nada yang mempunyai jarak 1 semitone pada nada ke 3-4, dan ke 7-8 (oktaf), serta jarak nada-nada yang lain adalah 1 tone. Dalam hal ini, tangga nada mayor natural merujuk pada tangga nada mayor di mana seluruh nada-nadanya belum mengalami perubahan (natural). Dalam notasi musik di tulis sebagai berikut :

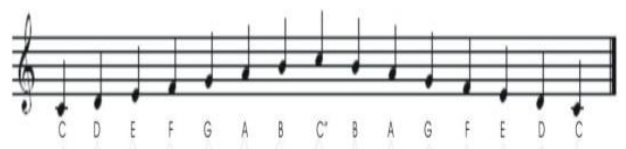

Gambar 8. Notasi Tangga Nada C

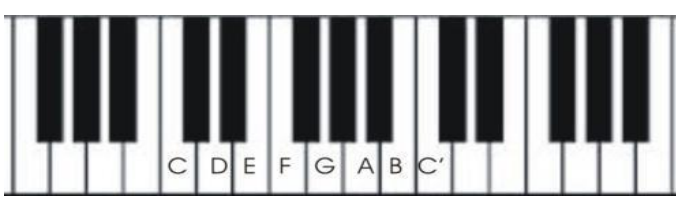

Gambar 9. Tuts Tangga Nada C 


\section{b. Tangga Nada Minor}

Tangga nada minor adalah susunan nada-nada yang memiliki jarak 1 semitone pada nada ke 2-3, dan 5-6, dan jarak nada-nada lain 1 semitone. Dengan susunan nada minor a-b-c-d-e-f-g-a.

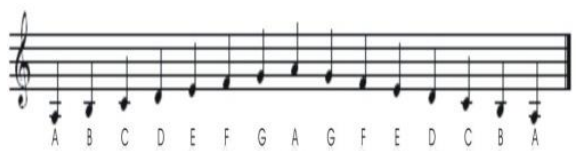

Gambar 10. Notasi Tangga Nada Minor

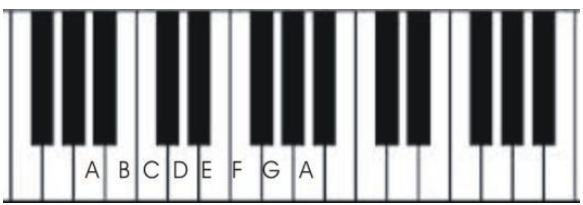

Gambar 11. Tuts Tangga Nada Minor

\section{Teknik Penjarian}

Menurut KBBI dijelaskan bahwa penjarian berasal dari kata jari, berarti ujung tangan atau kaki yang beruas, sedangkan penjarian adalah proses atau cara menyusun jari (Setiawan, 2012). Teknik penjarian merujuk pada cara untuk mencegah jari-jari agar tidak kaku ketika bermain musik. Pada hakekatnya, penjarian bertujuan untuk memudahkan jari-jari dalam memainkan instrumen musik, yaitu dengan memberi kode nomer penjarian pada masing masing jari tangan.

Dari pernyataan di atas dapat ditarik suatu kesimpulan bahwa penjarian merupakan urutan atau cara memainkan jari yang tersusun secara sistematis untuk membentuk jari yang teratur, selain itu penjarian juga mempunyai peranan yang paling esensial untuk membentuk pola permainan jari, sehingga memudahkan berkembangnya kemampuan jari dalam memperoleh keterampilan yang optimal dengan pemberian kode-kode pada jari sebagai berikut :

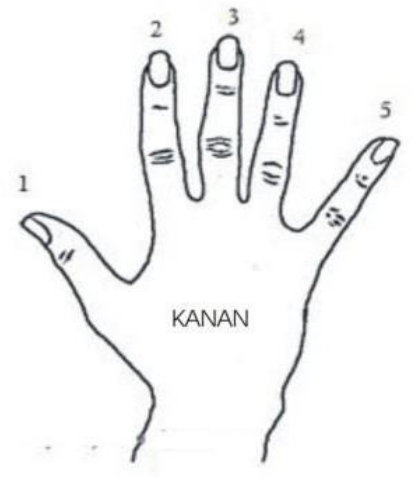

Gambar 12. Penjarian Pianika

Pada pianika, penjarian biasanya menggunakan tangan kanan yang terdiri dari :

a. Ibu jari, merujuk pada jari nomor 1 .

b. Jari telunjuk, merujuk pada jari nomor 2 .

c. Jari tengah, merujuk pada jari nomor 3 .

d. Jari manis, merujuk pada jari nomor 4 . e. Jari kelingking, merujuk pada jari nomor 5 .

Pada pembelajaran dengan menggunakan metode dalcroze, peserta didik diberikan pembelajaran mengenai euritmik, solfegio (latihan pendengaran) yang bertujuan untuk melatih pendengaran peserta didik khususnya terhadap bunyi/nada yang terdapat dalam notasi lagu, sehinga peserta didik dapat membedakan bunyi pada tiap-tiap not yang terdapat pada materi pianika.

Setelah itu peserta didik di berikan pembelajaran dan pembekalan berupa improvisasi. Adapun tujuan dari latihan tersebut adalah untuk meningkatkan keterampilan dan inovasi peserta didik agar lebih mengembangkan dan mengeksplor kemampuan melalui improvisasi secara musikal, ekspresif dalam memainkan alat musik dan responsif terhadap waktu, tempo, serta komunikatif terhadap rekan satu tim dalam bermusik.

\section{Memainkan Alat Musik}

Pada pertemuan ini, peneliti memberikan contoh kepada peserta didik terkait posisi baik dan benar untuk bermain pianika, mulai dari teknik/cara meniup pianika hingga posisi tangan dalam memegang pianika.

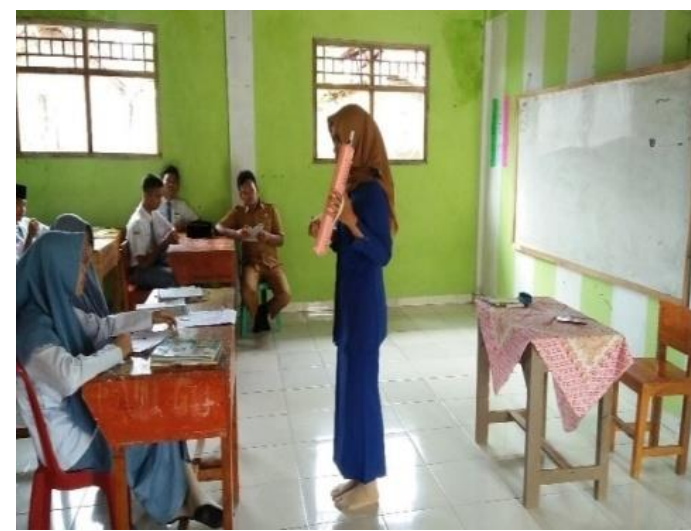

Gambar 13. Praktek Cara memegang pianika yang baik dan benar

(Dokumentasi Foto: Syaflinawati, Februari 2020)

Selanjutnya, peneliti memberikan materi berupa ritme lagu daerah yang telah dipersiapkan sebelumnya, yakni berupa ritme lagu Gundul-Gundul Pacul. Di mana peneliti menuliskan materi tersebut pada papan tulis dengan menyusun not seperti pada pertemuan sebelumnya, namun ketika not tersebut dimainkan dengan tepukan tangan akan menghasilkan ritme lagu Gundul-Gundul Pacul.

Langkah selanjutnya adalah memberikan instruksi kepada para peserta didik untuk memainkan not tersebut dengan menggunakan pianika. Sebelum masuk pada tahap tersebut, peserta didik diinstruksikan agar menyanyikan notasi angka secara bersama-sama sesuai dengan nada, ritme dan tempo yang baik dan benar. Pada tahap ini, peserta didik menyanyikanya dengan nada "sol mi sa si" sesuai simbol angka yang telah dituliskan. Setelah itu dipersilahkan kepada para peserta didik untuk memainkan nada tersebut dengan menggunakan pianika yang dimainkan secara bergantian pada setiap kelompok. 


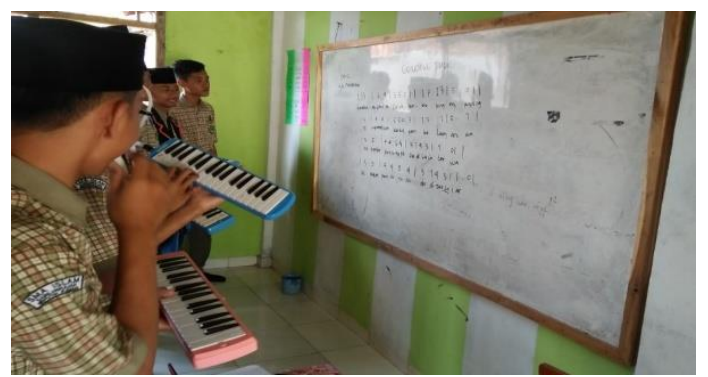

Gambar 14. Praktek memainkan lagu Gundul-Gundul Pacul

(Dokumentasi Foto: Syaflinawati, Maret 2020)

Pada kesempatan ini, peneliti memberikan keleluasaan kepada para peserta didik untuk bertanya jika mengalami kesulitan selama proses pembelajaran. Selanjutnya dilakukan review atau mengulang kembali kegiatan pembelajaran yang telah berlangsung. Pada pertemuan ini, peneliti memberikan mengapresiasi yang sangat baik, karena hampir semua peserta didik dapat mengikuti proses pembelajaran dengan baik dan benar. Walaupun masih ditemukan beberapa peserta didik yang belum lancar dalam memainkan lagu atau materi yang diberikan terutama dalam hal membaca ritme dan tempo pada lagu. Berdasarkan hasil praktek tersebut, peneliti menginstruksikan peserta didik agar mempelajari dan mengulang kembali materi yang telah diajarkan pada saat pembelajaran.

Pertemuan selanjutnya, peserta didik diinstruksikan untuk memainkan ulang lagu atau materi yang telah dipelajari pada pertemuan sebelumnya, yakni lagu Gundul-Gundul Pacu. Selanjutnya dilakukan pengambilan nilai secara individu sesuai urutan presensi. Adapun hal-hal yang menjadi point penilaian meliputi ritme, tempo, ketepatan nada dan posisi yang benar dalam memainkan pianika. Pada tahap pertama peserta didik diberi waktu 15 menit untuk belajar secara mandiri, setelah itu peneliti akan memanggil satu persatu peserta didik untuk memainkan lagu sesuai materi yang telah diberikan, dalam hal ini, peneliti akan memanggil para peserta didik berdasarkan pada urutan sebagaimana yang telah tercantum pada absensi.

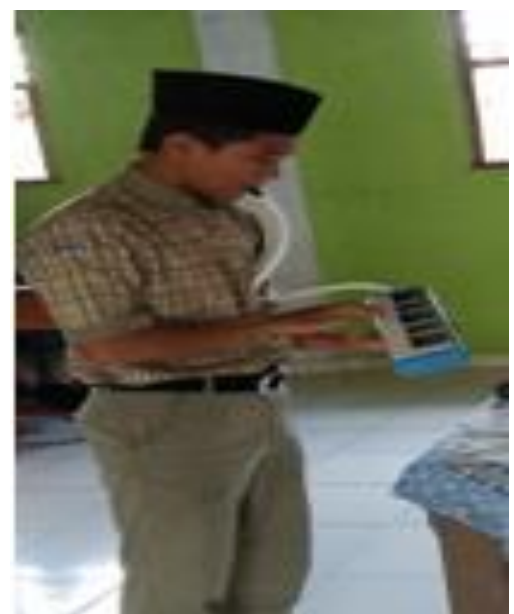

Gambar 15. Tes Individu lagu Gundul-Gundul Pacul menggunakan pianika.

(Dokumentasi Foto: Syaflinawati, 2020)

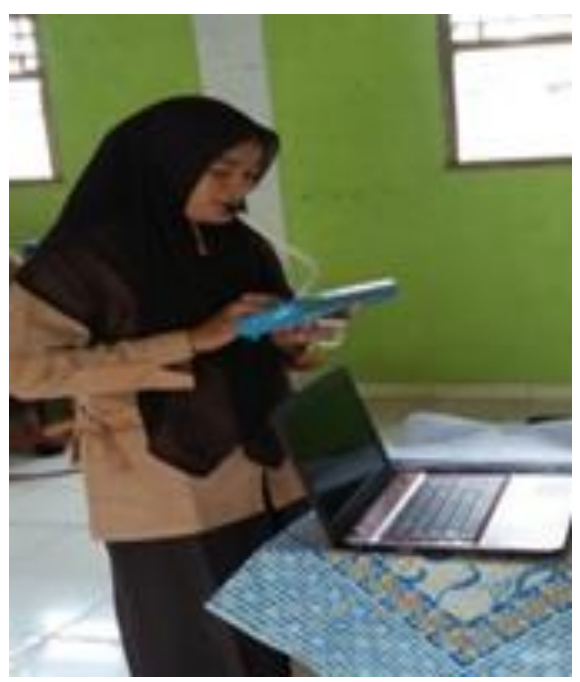

Gambar 16. Tes Individu lagu Gundul-Gundul Pacul menggunakan pianika

(Dokumentasi Foto: Syaflinawati, 2020)

Selanjutnya peneliti melakukan review kembali terhadap hasil praktek yang telah dilaksanakan. Pada tahap review ini masih ditemukan peserta didik yang menguasai/mahir dalam memainkan alat musik pianika tersebut. Dalam hal ini, peneliti memberikan kesempatan kepada para peserta didik yang belum mahir agar mempelajari kembali materi yang telah diajarkan.

Adapun tujuan dilakukan tes praktek pianika adalah untuk mengetahui tingkat kemampuan para peserta didik dalam memainkan alat musik pianika dengan penggunaan metode dalcroze melalui pembacaan notasi musik, posisi permainan pianika, memainkan lagu dengan baik dan benar. Untuk meningkatkan kemampuan peserta didik, ada baiknya di mulai menggunakan lagu dengan nada, tempo, irama yang mudah, artinya dapat dipahami oleh peserta didik. Adapun lagu yang sangat mudah dipahami oleh peserta didik adalah lagu Gundul-Gundul Pacul.

\section{Kesimpulan}

Berdasarkan hasil penelitian yang telah dilakukan, dapat disimpulkan bahwa metode dalcroze dapat meningkatkan kemampuan para peserta didik untuk memainkan alat musik pianika pada saat pembelajaran pianika di SMA Negeri 1 Tanjung Raja. Pembelajaran ini termasuk kedalam pelajaran praktek yang dapat meningkatkan skill dan kemampuan peserta didik dalam memainkan alat musik tersebut. Selain itu, praktek/latihan pianika juga bertujuan untuk meningkatkan kreatifitas peserta didik dalam hal memainkan alat musik, baik berupa lagu nasional maupun lagu tradisional.

Untuk meningkatkan kemampuan bermain pianika dengan menggunakan metode dalcroze dapat dilakukan dengan cara menerapkan pelatihan eurhythmik, solfege dan improvisasi. Di mana eurhythmic dalcroze mengajarkan tentang konsep ritme, struktur, dan ekspresi musik dengan menggunakan gerakan. Solfege 
bermanfaat untuk mengidentifikasi kepekaan musikal, baik itu kemampuan mengidentifikasi ritmik maupun kemampuan mengidentifikasi melodi. Sedangkan improvisasi merujuk pada kemampuan untuk mengembangkan sesuatu secara spontanitas, kreatifitas, daya cipta, dan daya khayal. Oleh karena itu sangat tepat rasanya diterapkan metode dalcrozer materi ajar pianika.

\section{Daftar Pustaka}

Allen Winold, and Jhon Rehn. 1971. Introduction to Music Theory. United State of America : PRENTICE HALL.

Banoe, Pono. 2011. Kamus Musik. Yogyakarta : Kanisius.

Jamalus. 1988. Panduan Pengajaran Buku Pengajaran Musik Melalui Pengalaman Musik. Jakarta: Proyek Pengembangan Lembaga Pendidikan.

Mudjilah, Hanna Sri. 2004. Teori Musik (Diktat Kuliah). Yogyakarta: Jurusan Sendratasik Program Studi Pendidikan Seni Musik, FBS-UNY Yogyakarta.

Muhammad Irham, et. all. 2013. Psikologi Pendidikan: Teori dan Aplikasi dalam Proses Pembelajaran. Yogyakarta: Ar-Ruzz Media.

Nata, Abuddin. 2009. Perspektif Islam tentang Strategi Pembelajaran. Jakarta: Kencana.

Tarmizi, dkk. 2019. Studi Deskriptif Penerapan Alat Musik Pianika Pada Mata Pelajaran Seni Budaya dan Keterampilan (SBK) Siswa Kelas 5 SDN 35 Kota Bengkulu. E-Jurnal PGSD) Vol. 12 (1). Universitas Bengkulu.

Safrina, Rien. 1999. Pendidikan Seni Musik. Bandung: Maulana.

Setiawan Adhi, Arifin dan Zainal. 2012. Pengembangan Pembelajaran Aktif dengan ICT. Yogyakarta: Skripta Media Creative.

Sugiyono. 2015. Metode Penelitian Kombinasi (Mix Methods). Bandung: Alfabeta.

Undang-Undang Republik Indonesia Nomor 20 Tahun 2003, tentang Sistem Pendidikan Nasional

Peraturan Menteri Pendidikan Nasional Republik Indonesia Nomor 41 Tahun 2007, Tentang Standar Proses Untuk Satuan Pendidikan Dasar dan Menengah 